\title{
Vermicomposting Process to Endosulfan Lactone Removal in Solid Substrate Using Eisenia fetida
}

\author{
Paola T. Vázquez-Villegas ${ }^{1, *}$, Rocío Meza-Gordillo ${ }^{2}$, Abumalé Cruz-Salomón ${ }^{3} \mathbb{D}$, Víctor M. Ruíz-Valdiviezo ${ }^{2} \mathbb{D}$, \\ Federico A. Gutiérrez-Miceli ${ }^{2}$ (D), Juan J. Villalobos-Maldonado ${ }^{2}$, Joaquín A. Montes-Molina ${ }^{2}$, \\ Janet Aguilar-Vázquez ${ }^{2}$ and Zaira Domínguez ${ }^{4}$
}

1 Departamento de Ingeniería en Industrias Alimentarias, Tecnológico Nacional de México/ITS de Cintalapa, Carretera Panamericana km 995, Cintalapa de Figueroa 30400, Mexico

2 Departamento de Ingeniería Química y Bioquímica, Tecnológico Nacional de México/IT de Tuxtla Gutiérrez, Carretera Panamericana km 1080, Tuxtla Gutiérrez 29050, Mexico; rocio.mg@tuxtla.tecnm.mx (R.M.-G.); bioqvic@hotmail.com (V.M.R.-V.); fgmiceli@gmail.com (F.A.G.-M.); juanjovillam@hotmail.com (J.J.V.-M.); monttes21@hotmail.com (J.A.M.-M.); jannethrizo920@gmail.com (J.A.-V.)

3 Escuela de Ciencias Químicas, Sede Ocozocoautla, Universidad Autónoma de Chiapas (UNACH), Carretera Panamericana Ocozocoautla-Cintalapa km 2.5, Ocozocoautla de Espinosa 29140, Mexico; dr.abumale@gmail.com

4 Unidad SARA, Universidad Veracruzana. Dr. Luis Castelazo Ayala s/n, Col. Industrial Ánimas, Xalapa 91190, Mexico; zdominguez@uv.mx check for
updates

Citation: Vázquez-Villegas, P.T.; Meza-Gordillo, R.; Cruz-Salomón, A.; Ruíz-Valdiviezo, V.M.; GutiérrezMiceli, F.A.; Villalobos-Maldonado, J.J.; Montes-Molina, J.A.; AguilarVázquez, J.; Domínguez, Z. Vermicomposting Process to Endosulfan Lactone Removal in Solid Substrate Using Eisenia fetida. Processes 2021, 9, 396. https://doi.org/10.3390/pr9020396

\section{Academic Editors:}

Avelino Núñez-Delgado and David Fernández-Calviño

Received: 31 December 2020 Accepted: 18 February 2021 Published: 22 February 2021

Publisher's Note: MDPI stays neutral with regard to jurisdictional claims in published maps and institutional affiliations.

Copyright: (c) 2021 by the authors. Licensee MDPI, Basel, Switzerland. This article is an open access article distributed under the terms and conditions of the Creative Commons Attribution (CC BY) license (https:// creativecommons.org/licenses/by/ $4.0 /)$.
* Correspondence: paolatayde@hotmail.com or ptayde@cintalapa.tecnm.mx; Tel.: +52-961-166-9901

\begin{abstract}
Pesticide by-products found in soil are usually more toxic and persistent than the pesticides themselves. For example, Endosulfan lactone (EL) (a by-product of the organochloride pesticide endosulfan). EL is created by the enzymatic activity (and related oxidative processes) of microorganisms in the soil. A sustainable method of EL removal is the introduction of Eisenia fetida earthworm. In this paper, it will be demonstrated the impact of vermicomposting process related to Eisenia fetida earthworm on EL by measuring initial and final concentrations of the compound and overall enzymatic activity in sterile and non-sterile solid substrate over 56 days. As a baseline, it be observed there were higher EL removals in non-sterile solid substrate (90.86\%) at day 5 than in sterile solid substrate $(83.86 \%)$ at day 14 . In samples with Eisenia fetida, the presence of EL in non-sterile solid substrate was $36 \%$, however in sterile solid substrate it was only $18 \%$ at day 1 and 7 , with a maximum enzyme activity of $0.4659 \mathrm{mmol} / \mathrm{mg}$ protein per min at day 7 . The evidence found in this study suggests that EL removal in a non-sterile solid substrate is higher when a vermicomposting is present and that the influence of microorganisms from the solid substrate with the earthworm, increases removal.
\end{abstract}

Keywords: cyp450 multienzyme complex; endosulfan lactone removal; enzymatic activity; microorganisms; organochloride pesticides; non-sterile solid substrate; sterile solid substrate

\section{Introduction}

Endosulfan is acutely toxic and facing a global ban. It has been specially applied for the control of aphids, beetles, caterpillars, mites, borers, bed bugs, moths, flies, and other insects in various crops such as coffee, cotton, cereals, tea, legumes, and fruit trees [1]. This pesticide is harmful to humans and for most animals, showing acute and chronic effects, even at low concentrations (10-160 $\mathrm{mg}$ of endosulfan $/ \mathrm{kg}$ soil) [2,3]. It was banned due to its residual nature, high toxicity, persistence, long-distance transport, and bioaccumulation in fatty tissues [1,4], so it is also part of the Persistent Organic Compounds (POC's) [5]. Despite the ban and acute environmental impact, some farmers continue to use endosulfan, which poses a serious threat to food security and human health.

Persistent use of endosulfan generates harmful by-products in the soil such as endosulfan lactone (EL) $\left(\mathrm{C}_{9} \mathrm{H}_{4} \mathrm{Cl}_{6} \mathrm{O}_{2}\right)$, which has been identified in soil up to six years after the first exposure. This molecule is generated by the oxidation of endosulfan (Figure 1) [2-4,6], 
and has a polar structure that makes it toxic, persistent, and bioaccumulative [4]. One solution is the vermicomposting process, which can aid in the removal of certain POC's from soil, add nutrients and stimulate crop production.
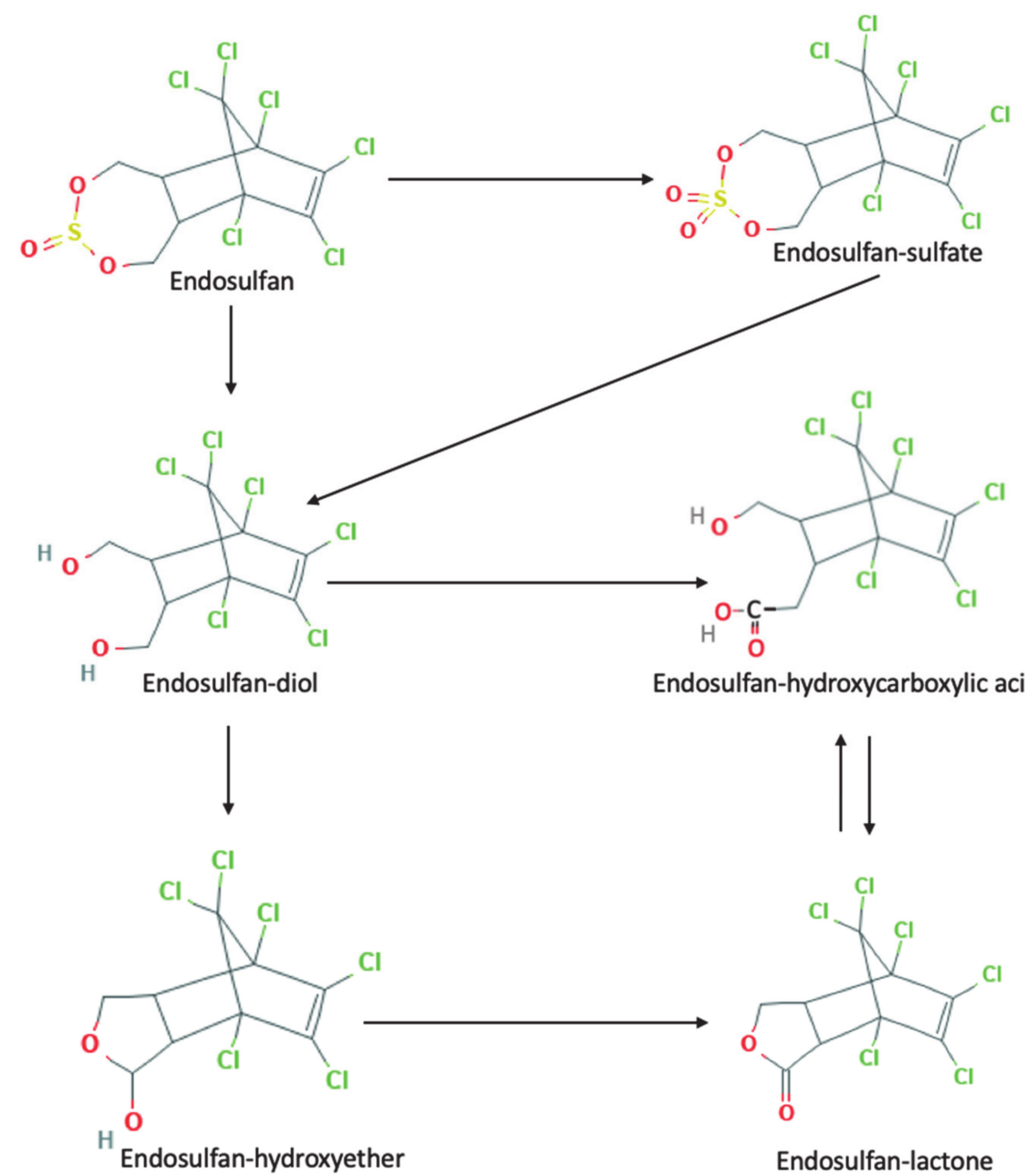

Endosulfan-hydroxycarboxylic acid

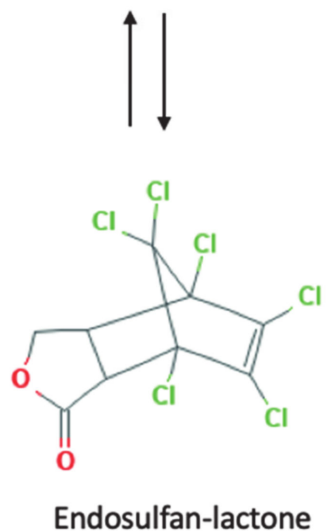

Figure 1. Degradation of endosulfan pesticide to endosulfan lactone by-product.

Vermicomposting is a low-cost eco-technological process that stimulates the biooxidation, degradation, and stabilization of organic residues in soil via the joint action of earthworms and microorganisms $[5,7,8]$. This efficient technological process can convert organic waste and contaminants into value-added products for ecological soil restoration [9].

The vermicomposting process (Figure 2) has three stages. In the first stage, the waste materials decompose by means of microorganisms (generally bacteria) working in tandem with earthworms. The two produce a homogeneous mixture of the substrate, which aerates and facilitates degradation in the soil. In this stage, the temperature begins at approximately $15{ }^{\circ} \mathrm{C}$, however it increases due to the energy (metabolism) generated by the process, this increases of temperature (up to $50^{\circ} \mathrm{C}$ ) give way to the second stage called digestion. In the digestion phase, degradation of simple and semi-complex organic wastes in the substrate begins, with the help of some fungi, actinomycetes, and some derivatives of the digestive tract of the earthworm [10]. In the last stage, maturation and cooling, the rocky aggregates are stabilized, creating a homogeneous final product with fine granulometry. 


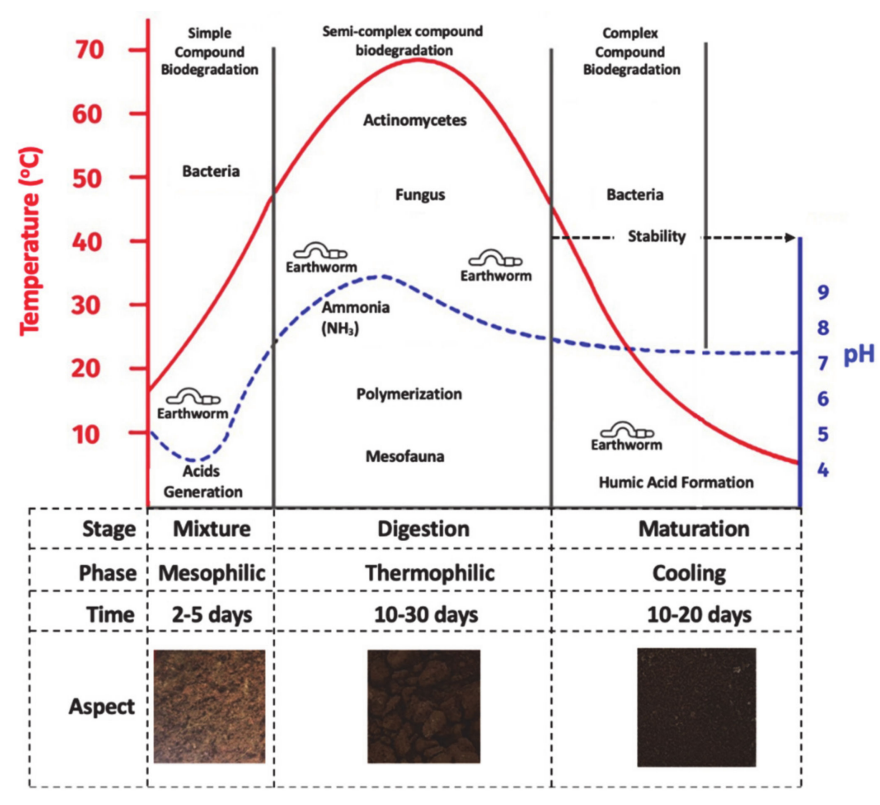

Figure 2. Vermicomposting process in the solid substrate.

Earthworms, such as Eisenia fetida (common names such as redworm, brandling worm, panfish worm, trout worm, tiger worm, and red wiggler worm), promote the removal of POC's such as polycyclic aromatic hydrocarbons ( $\mathrm{PAH}^{\prime} \mathrm{s}$ ) [7] and polychlorinated biphenyls (PCB's) [8]. Eisenia fetida also feed on organic matter and contaminants present in the soil, improving its structure and aeration [9]. Making use of adsorption and absorption processes within vermicomposting, the interaction of the contaminant with the substrate and the earthworm is increased.

\section{Materials and Methods}

\subsection{Chemicals}

Endosulfan lactone and $6 \beta$-hydroxytestosterone were used as analytical standard (purity $>99 \%$ ), provided by Sigma-Aldrich (St. Louis, MO, USA). Testosterone was provided by Bayer ${ }^{\circledR}$ (Ciudad de Mexico, Mexico). Molecular marker Precision Plus Protein (10-250 kD) was provided by Bio-Rad Laboratories (Ciudad de Mexico, Mexico). Acetonitrile, methylene chloride, acetone, and methanol were HPLC grade (purity $\geq 99.9 \%$ ) and provided by Sigma-Aldrich (St. Louis, MO, USA). Potassium phosphate, magnesium chloride, glucose-6 -phosphate, glucose-6-phosphate dehydrogenase, and NADPH were gradient grade provided by Sigma-Aldrich (St. Louis, MO, USA). Coomassie blue G250 and SDS were electrophoresis purity and provided by Bio-Rad Laboratories (Mexico). Glycine and Tris-base were electrophoresis purity and provided by Sigma-Aldrich (St. Louis, MO, USA).

\subsection{Raw Material and Solid Substrate}

Rabbit manure used in this study was collected from a rabbit farm located in Tuxtla Gutiérrez, Mexico (latitude $16^{\circ} 45^{\prime} 11^{\prime \prime} \mathrm{N}$ and longitude $93^{\circ} 6^{\prime} 56^{\prime \prime} \mathrm{W}$ ). It was dried and milled to particle diameter $(0.144 \mathrm{~mm})$. Peat moss was a commercial product, obtained from Promix Canadian Sphagnum (Quebec, QC, Canada); it was milled to particle diameter $(0.144 \mathrm{~mm})$ and used as support for the earthworms. The solid substrate used was composed by $85 \%$ peat moss and $15 \%$ pre-dried and ground rabbit manure [8].

Earthworms (Eisenia fetida) were obtained from the Luanda Ranch, located in the municipality of Ocozocoautla de Espinosa, Mexico (latitude $16^{\circ} 45^{\prime} 41.26^{\prime \prime} \mathrm{N}$ and longitude $93^{\circ} 22^{\prime} 32.35^{\prime \prime} \mathrm{W}$ ). Prior to the research, earthworms were matured in peat moss and rabbit manure for 2 months. Subsequently, adult earthworms with developed clitellum (sexually mature) were selected for the experiment. 


\subsection{Physicochemical Characteristics of the Solid Substrate and Vermicompost}

The solid substrate and vermicompost were analyzed according to the Official Mexican Environmental Regulations [11]. Parameters measured were $\mathrm{pH}$, moisture, inorganic nitrogen, total nitrogen (TN), real density, and organic matter [11]. The total organic carbon (TOC) was determined by the method of Walkley and Black [12] and $\mathrm{C} / \mathrm{N}$ ratio was determined according to that reported by Durán and Henríquez [13]. All the tests were performed by triplicate.

\subsection{Removal Process}

The experimental units were $1 \mathrm{~L}$ amber glass jars with $50 \mathrm{~g}$ of solid substrate $(85 \%$ peat moss and $15 \%$ rabbit excreta), covered with a cotton cloth to promote aeration. The humidity was adjusted to $70 \%$ with distilled water. Three concentrations of EL (determined by mean lethal concentration (LC50) $[14,15]$ ) and two quantities of earthworms were used. Units were kept at a constant ambient temperature of $25^{\circ} \mathrm{C} \pm 2{ }^{\circ} \mathrm{C}$ in a closed room with natural light. Every third day the substrate was manually homogenized, taking care not to stress the earthworms of each experimental unit. The removal process was carried out using solid substrate under non-sterile and sterile conditions; solid substrate sterilization was done according to the technique proposed by Peñaloza et al. [16] with slight modifications. Briefly, autoclave sterilization at $121{ }^{\circ} \mathrm{C}$ at $15 \mathrm{lb}$ pressure for $20 \mathrm{~min}$, three consecutive days. The test was performed for 56 days, the EL removal was measured on days $0,1,3,5,7,14,28$, and 56 within solid substrate and earthworms, analyzed using a simple ANOVA $(p<0.05)$ and Tukey HSD method by triplicate. It should be mentioned that on each sampling day, the flasks of that day were taken and the substrate was separated from the earthworm for subsequent analysis in HPLC-UV; no new substrate was applied to any bottle.

The determination of EL in the solid substrate was carried out in accordance with that described by Li et al. [17] and Vázquez-Villegas et al. [18,19] with slight modifications. Briefly, $12 \mathrm{~g}$ of substrate with $75 \mathrm{~mL}$ of acetonitrile and $120 \mathrm{~min}$ of rotary agitation at $175 \mathrm{rpm}$. Determination of EL in earthworm was carried out in accordance with that reported by Mosleh et al. [20] and Aguilar-Vázquez [21] using methylene chloride:acetone (5:1) with $2 \mathrm{~g}$ of sample and $120 \mathrm{~min}$ of rotary agitation at $175 \mathrm{rpm}$, washing three times and centrifuging at $9500 \mathrm{rpm}$ for $5 \mathrm{~min}$ at $4{ }^{\circ} \mathrm{C}$. Both supernatants were used for high performance liquid chromatography analysis coupled to UV (HPLC-UV) $[16,17]$. The EL removal efficiency was determined using Equation (1) [22].

$$
\operatorname{Removal}(\%)=\frac{[\mathrm{EL}]_{i}-[\mathrm{EL}]_{f}}{[\mathrm{EL}]_{i}} \times 100
$$

where $[\mathrm{EL}]_{i}$ is initial endosulfan lactone concentration, and $[\mathrm{EL}]_{f}$ final endosulfan lactone concentration.

\subsection{Optimization to EL Removal}

For the optimization of the removal process a $3^{2}$ response surface design with by triplicate was used, with 27 experimental units; the results were analyzed through a multifactor ANOVA design using the statistical software STATGRAPHICS Centurion XVI ${ }^{\circledR}$, as shown in Table 1.

Table 1. Factors used in the optimization of endosulfan lactone removal.

\begin{tabular}{cc}
\hline Endosulfan Lactone (mg/kg) & Earthworm (Number) \\
\hline 0.001 & 0 \\
\hline 0.004 & 5 \\
\hline 0.009 & 10 \\
\hline
\end{tabular}




\subsection{Enzyme Activity Measurement}

Once the removal process was analyzed and optimized, earthworm enzyme activity was evaluated during the 14 days of the experiment. This was achieved by exposing the earthworms' microsomes to $0.004 \mathrm{mg}$ endosulfan lactone $/ \mathrm{kg}$ solid substrate. The results were derived from the LC50 in artificial substrate tests [13] over 14 days taking samples on days $3,5,7$, and 14 and as a control the results of day zero $(0 \mathrm{mg} / \mathrm{kg})$. First, the amount of protein was measured based on the method of Folin-Lowry [23]. Then, the microsomes were obtained based on the methodology of Zhang et al. [24] and Cao et al. [25] with slight modifications. Briefly, the activity of the subunit of the cytochrome P450 (CYP450) CYP3A4 multienzyme complex was determined as an activity of $6 \beta$-hydroxystestosterone having testosterone as a substrate, this being the most used as hydroxyl are available for enzyme coupling.

The incubation system $(200 \mu \mathrm{L})$ contained $60 \mu \mathrm{M}$ testosterone, $3.3 \mathrm{mM} \mathrm{MgCl}$, $0.2-0.5 \mathrm{mg} / \mathrm{mL}$ microsomal protein, $3.3 \mathrm{mM}$ glucose-6-phosphate, and $0.4 \mathrm{U} / \mathrm{mL}$ glucose- 6 phosphate dehydrogenase and it was maintained at $\mathrm{pH} 7.4$ with $0.1 \mathrm{M}$ potassium phosphate buffer. The negative control was prepared without microsomal protein. The mixture was pre-incubated at $30^{\circ} \mathrm{C}$ for $5 \mathrm{~min}$. The reaction was initiated by the addition of $1 \mathrm{mM}$ of $\mathrm{NADPH}$ (serving as an $\mathrm{H}^{+}$donor) and was terminated by the addition of $100 \mu \mathrm{L}$ of ice-cold methanol after a $30 \mathrm{~min}$ incubation. The samples were centrifuged at $10,000 \mathrm{rpm}$ for $15 \mathrm{~min}$ and the aliquot of the supernatant was injected directly for HPLC-UV analysis.

The testosterone and $6 \beta$-hydroxytestosterone were quantified at $254 \mathrm{~nm}$, using a HPLC-UV (Agilent, Santa Clara, CA, USA) by the following conditions: C18 reverse phase column $(5 \mu \mathrm{m} \times 4.6 \mathrm{~mm} \times 250 \mathrm{~mm})$; mobile phase A of methanol-water-acetonitrile (39:60:1, v/v) and mobile phase $B$ of methanol-water-acetonitrile $(80: 18: 2, \mathrm{v} / \mathrm{v})$; flow rate of $0.7 \mathrm{~mL} / \mathrm{min}$ for $30.5 \mathrm{~min}$ at a rate of $50 \% \mathrm{~A}$ and $50 \% \mathrm{~B}$, and $52 \mathrm{~min}$ at a rate of $30 \% \mathrm{~A}$ and $70 \% \mathrm{~B}$.

\subsection{SDS-PAGE Electrophoresis}

The sodium dodecyl polyacrylamide gel electrophoresis (SDS-PAGE) was used to determine the approximate molecular weight of the microsomes obtained from the earthworms exposed to EL, which according to Li et al. [17] refers to cytochrome P450, whose expression is higher due to the presence of external stressors such as POPs and whose molecular weight can be corroborated with this technique. The SDS-PAGE was performed following the methodology described by Laemmli [26] and Li et al. [27], with slight modifications. Briefly, the separating gel was $15 \%$ and the stacking gel was $4 \%$. Electrophoresis was carried out in a mini-Protean electrophoresis chamber. The gel was stained with Coomassie $1 \%$. The electrophoresis conditions were the following: $80 \mathrm{~V}$ for $60 \mathrm{~min}$ and $50 \mathrm{~V}$ for $60 \mathrm{~min}$ using a $1 \times$ running buffer (Tris/Glycine/SDS). The obtained standards were compared with the standard (molecular marker).

\section{Results and Discussions}

\subsection{Physicochemical Characteristics of Solid Substrate and Vermicompost}

Use a solid substrate increased the availability of nutrients, organic matter, and microorganisms for vermicomposting, and thus created substrates similar to clay soil and sandy soils. Further, the solid substrate simulated a neutral environment for the growth and development of earthworms without any external stressor (other than the contaminant in question).

The physicochemical parameters shown in Table 2 refer to the solid substrate and the vermicompost made after 56 days. By then, earthworms already fed on the substrate and excreted vermicompost. The results demonstrate that vermicompost can be used in 1:1 ratio with standard agricultural soil to increase the availability of nutrients and provide optimum soil for plant growth on agricultural land, this being a sustainable alternative to increase the richness of the soil. 
The solid substrate has less humidity in relation to the vermicompost, because the solid substrate is adjusted to $70 \%$ humidity to allow earthworms to take the necessary nutrients from it and have better mobility. Regarding $\mathrm{pH}$, both the solid substrate and the vermicompost have a neutral or slightly basic $\mathrm{pH}$. That is because earthworms can stabilize the $\mathrm{pH}$ of the food they eat, due to the fact that they secrete calcium carbonate which balances the soil's pH [13].

The solid substrate contains a high content of inorganic nitrogen ( $48 \mathrm{mg} / \mathrm{kg}$ ), present in the form of nitrates, nitrites, and ammonium. These are absorbed by plants and are part of plant nutrition. So, it is related to the total nitrogen content $(0.25 \%)$, present in the form of proteins, amino acids, etc. These not only forming part of the soil, but also the microorganisms that inhabit it [28]. In turn, the microorganisms help in the formation of vermicompost. As for the content of organic matter, it is related to nitrogen content. That is, if the nitrogen content is high, the organic matter is high; this may be due to external factors such as atmospheric temperature and excess moisture which, favor the availability of microorganisms, which is completely related to the removal process of this research.

Table 2. Physicochemical characteristics of solid substrate and vermicompost.

\begin{tabular}{|c|c|c|c|c|}
\hline Parameter & Solid Substrate & Vermicompost & Reference Values & References \\
\hline Moisture (\%) & $36 \pm 5.6$ & $92 \pm 2.6$ & - & \multirow{4}{*}{ [11] } \\
\hline $\mathrm{pH}$ & $6.9 \pm 0.08$ & $7.3 \pm 0.02$ & $\begin{array}{c}\text { Strongly acidic }(<5.0) \\
\text { Moderately acidic }(5.1-6.5) \\
\text { Neutral }(6.6-7.3) \\
\text { Moderately alkaline }(7.4-8.5) \\
\text { Strongly alkaline }(>8.5)\end{array}$ & \\
\hline $\mathrm{N}_{\text {Inorganic }}(\mathrm{mg} / \mathrm{Kg})$ & $48 \pm 1.9$ & $56 \pm 5.8$ & $\begin{array}{l}\text { Very low }(0-10 \mathrm{mg} / \mathrm{Kg}) \\
\text { Low }(10-20 \mathrm{mg} / \mathrm{Kg}) \\
\text { Medium }(20-40 \mathrm{mg} / \mathrm{Kg}) \\
\text { High }(40-60 \mathrm{mg} / \mathrm{Kg}) \\
\text { Very high }(>60 \mathrm{mg} / \mathrm{Kg})\end{array}$ & \\
\hline $\mathrm{N}_{\text {Total }}(\%)$ & $0.25 \pm 0.002$ & $0.30 \pm 0.008$ & $\begin{array}{c}\text { Very low }(<0.05 \%) \\
\text { Low }(0.05-0.10 \%) \\
\text { Medium }(0.10-0.15 \%) \\
\text { High }(0.15-0.25 \%) \\
\text { Very high }(>\mathbf{0 . 2 5 \%})\end{array}$ & \\
\hline Real density $\left(\mathrm{g} / \mathrm{cm}^{3}\right)$ & $1.05 \pm 0.006$ & $1.19 \pm 0.006$ & $\begin{array}{c}\text { Very low }(<2.4) \\
\text { Low }(2.4-2.60) \\
\text { Medium }(2.60-2.80) \\
\text { High }(>2.80)\end{array}$ & [29] \\
\hline $\begin{array}{c}\text { Organic matter } \\
(\%)^{a}\end{array}$ & $7.3 \pm 0.34$ & $10.9 \pm 0.26$ & $\begin{array}{l}\text { Very low }(<0.5 \%) \\
\text { Low }(0.6-1.5 \%) \\
\text { Medium }(1.6-3.5 \%) \\
\text { High }(3.6-6.0 \%) \\
\text { Very high }(>6.0 \%)\end{array}$ & [11] \\
\hline TOC (\%) & $7.48 \pm 0.26$ & $14.15 \pm 0.69$ & - & \\
\hline $\mathrm{C} / \mathrm{N}$ & 29.92 & 47.17 & $\begin{array}{l}\mathrm{C} / \mathrm{N} \text { low }(<10) \\
\mathrm{C} / \mathrm{N} \text { high }(>25)\end{array}$ & {$[13,30]$} \\
\hline
\end{tabular}

\footnotetext{
a The organic matter was analyzed using the Walkley and Black [12] methodology, in which between $70 \%$ and $84 \%$ of the total organic carbon is
} detected, so it is necessary to introduce a correction factor of 1.298. Each value represents the mean of 3 replicates \pm standard deviation.

Vermicompost has a high nitrogen content $(0.30 \%)$, which improves the availability of nitrogen in the soil for plants and is related to the theoretical obtaining of organic carbon values $(14.15 \%)$ as a carbon/nitrogen $(\mathrm{C} / \mathrm{N})$ ratio that indicates the potential of the soil to transform organic matter into mineral nitrogen. 
The Environmental Protection Agency (EPA) [31], recommends the use of soils with a $\mathrm{C} / \mathrm{N}$ ratio of 50 to 100 for the biodegradation of soils contaminated with hydrocarbons, because higher amounts of carbon more efficiently aid assimilation of pollutants by soil microorganisms [32]. The vermicompost obtained from solid substrate vermicomposting has a $\mathrm{C} / \mathrm{N}$ ratio close to that required by the EPA, which suggests that it is a viable option for the use of bioremediation of contaminated soils and removal of contaminants such as EL.

\subsection{Non-Sterile Solid Substrate}

\subsubsection{Endosulfan Lactone Removal on Non-Sterile Solid Substrate}

The EL removal percentages obtained in non-sterile solid substrate throughout the days of sampling are observed in Figure 3; in which it can be seen that the removals are $<20 \%$ for zero earthworms this percentage is due to the presence of microorganisms in the substrate. Substrate with 5 and 10 earthworms had greater removal on day 5 (85-95\%) for the three concentrations used. There is no significant statistical difference on days 7 and 14 for 5 and 10 earthworms in the concentration of $0.004 \mathrm{mg} / \mathrm{kg}$ (Figure 3B) and $0.009 \mathrm{mg} / \mathrm{kg}$ (Figure 3C); however, there was a statistical difference in concentration of $0.001 \mathrm{mg} / \mathrm{kg}$ (Figure 3A). As of day 14, removal decreases without statistically significant difference for 5 and 10 earthworms at the concentration of $0.009 \mathrm{mg} / \mathrm{kg}$ (Figure 3C); however, there is a significant statistical difference between 5 and 10 earthworms at concentrations of 0.001 and $0.004 \mathrm{mg} / \mathrm{kg}$ on days 28 and 56 (Figure 3A,B). For the three concentrations, the removal increases slightly in the samples without earthworms at day 56, which may be due to the composting process carried out by the microorganisms of the substrate. That said, EL removal is greater in samples containing earthworms. One reason being that the earthworms form grooves in their mid-sections where they are aerating and mixing the soil. These grooves improve the availability of nutrients for the microorganisms and for themselves.

The results of the natural removal process are variable since it is a system with living organisms and changing conditions. In this investigation, external factors such as temperature, humidity and light were controlled. As a result, we found each individual organism behaved differently; however, similar behavior was observed in groups of 5 to 10 earthworms.

Coutiño-González et al. [33], evaluated the removal of anthracene using Eisenia fetida and found a removal of $41 \%$ and $93 \%$ in earthworm's experiments, over 70 days, thus demonstrating how earthworms effectively accelerates the removal of contaminants in soil, conditioning the substrate and altering the biological activity.

Earthworms also stimulate microbial activity through the excretion of degradable carbon. Microbial activity in turn accelerates the degradation of organic matter, which ultimately assists in the removal of contaminants (and the degradation products from contaminants) from the soil [9].

Moreover, Ali et al. [34], evaluated the removal of endosulfan $\alpha$ and $\beta$, using a plant residue compost using a continuous large-scale rotary drum composter, having $84.95 \%$ and $83.20 \%$ removals for endosulfan $\alpha$ and $\beta$ respectively at eight days. They had a microbial consortium that included Bacillus sp., Pseudomonas sp., and Lactobacillus sp. and concluded that the removal technique is capable of eliminating organochlorine pesticide compounds from vegetables because the synergy of composter and microorganisms accelerates the removal of contaminants.

Combined with this research, it has found microorganisms working together with earthworms do an excellent job in a short time (56 days) of removing contaminants. Additionally, the application of this EL removal process helps in bioremediation of contaminated soils where pesticide products remain for more than 10 years and are difficult to remove.

Examples of microorganisms that could be involved in the removal process would be Rhodococcus strains, specifically Rhodococcus MTCC 6716, extracted from the Metaphire posthuma worm, which has been able to degrade endosulfan to $92.58 \%$ in 15 days [35], Pusillimonas sp. JW2 and Bordetella petrii NS strains, isolated of endosulfan contaminated en- 
vironments, having more than $95 \%$ degradation of endosulfan to alpha and beta endosulfan in an in-situ bioremediation [36].
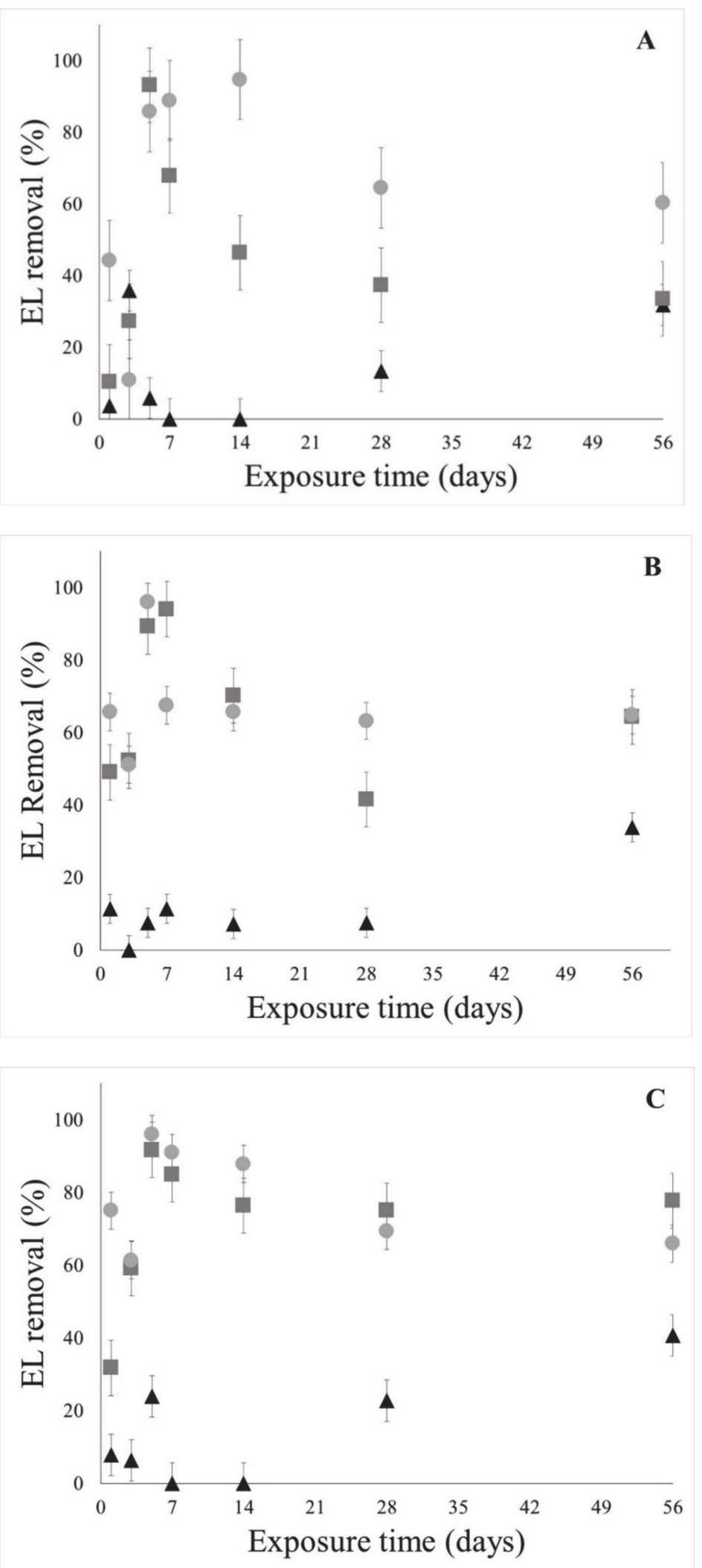

Figure 3. Endosulfan Lactone (EL) removal (\%) on non-sterile solid substrate with (A) $0.001 \mathrm{mg} / \mathrm{kg}$, (B) $0.004 \mathrm{mg} / \mathrm{kg}$ and $(\mathbf{C}) 0.009 \mathrm{mg} / \mathrm{kg}$ for zero $(\boldsymbol{\Delta})$, five (ם) and ten $(\bullet)$ earthworms. 


\subsubsection{Endosulfan Lactone in Earthworm}

It was essential to evaluate the presence of EL in the earthworm, in order to evaluate the effect of the contaminant on Eisenia fetida. An important factor was the route of entry of the pollutants into the earthworm, either through its tegument or its gastrointestinal tract. The phenomenon of adsorption is greater in the tegument than gastrointestinal tract [37].

Analyzing the presence of EL in earthworms (Figure 4), it can be observed that the highest concentration is found on day 1 , decreasing as the days pass without statistically significant difference between $0.001 \mathrm{mg} / \mathrm{kg}$ and $0.004 \mathrm{mg} / \mathrm{kg}$ and between 5 and 10 earthworms.

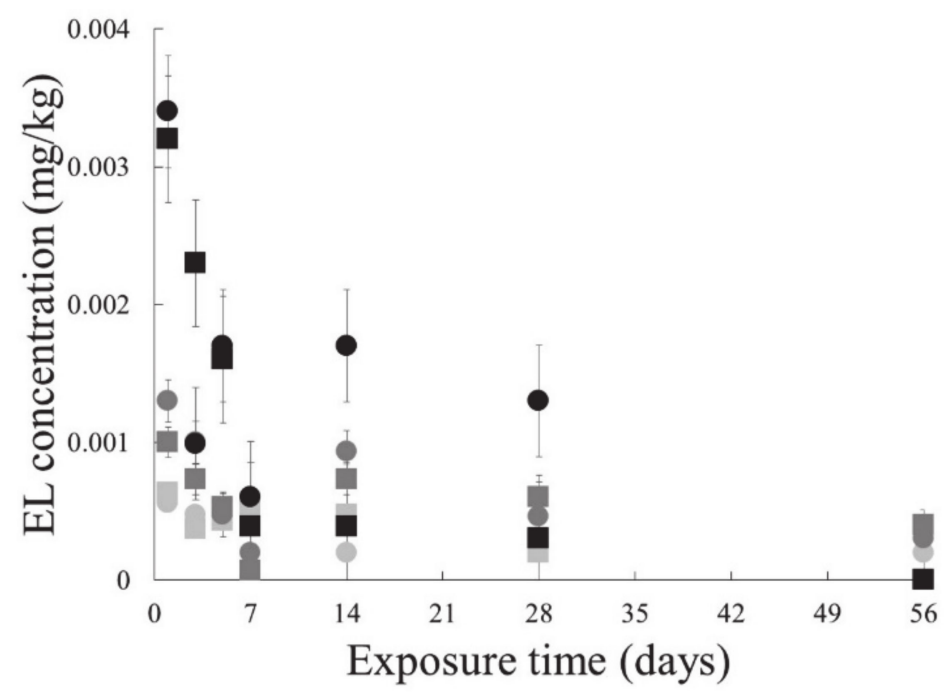

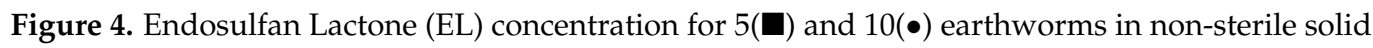
substrate with $0.001 \mathrm{mg} / \mathrm{kg}$

From day 1 to 3, earthworms go through an adaptation process in which they consume the largest amount of substrate. This is due to stressor agents found in the environment (for example EL) and simply trying to survive. Next, earthworms begin to excrete vermicompost, which is reported as a nutritious organic fertilizer, rich in micronutrients and microorganisms beneficial to the soil such as nitrogen fixing bacteria and actinomycetes, as well as some growth hormones [38]. As of day 5, the earthworms begin to perform removal functions that are conducive to the removal of persistent organic compounds, which create synergy between the earthworms, their functions, and their excreta, as well as the properties and microorganisms contained in the substrate. Earthworm dejections have a very large microbiota richness, with about $2 \times 10^{12}$ colonies/g of humus produced [13].

It should be noted that, Kauschke et al. [39] and Bilej et al. [40] reported the celomic fluid of earthworms (a by-product of their immune system, which can be stimulated by external stress), can act in two ways: (a) Eliminating any substance by phagocytosis, that is, encapsulating the component in question for its subsequent excretion to the environment; (b) Increasing the enzymatic activity to transform the pollutant molecules into more polar ones that can be exploited by the microorganisms of the digestive tract of the earthworm or those found in the environment in which it lives.

This process can be stimulated in earthworms when affected by EL.

\subsection{Sterile Solid Substrate}

\subsubsection{Endosulfan Lactone Removal on Sterile Solid Substrate}

EL removal percentages found in sterile solid substrate shown in Figure 5. Notice that removal is less in the first three days; however, it increases from day 5 for 5 and 10 earthworms and for $0.004 \mathrm{mg} / \mathrm{kg}$ (Figure 5B) and $0.009 \mathrm{mg} / \mathrm{kg}$ (Figure 5C), with no statistically significant difference. Removal otherwise occurs in the concentration of $0.001 \mathrm{mg} / \mathrm{kg}$ (Figure 5A) where 
the maximum removal is obtained at 7 days with 10 earthworms having significant statistical difference between day 7 and 14 and between 0,5 , and 10 earthworms.
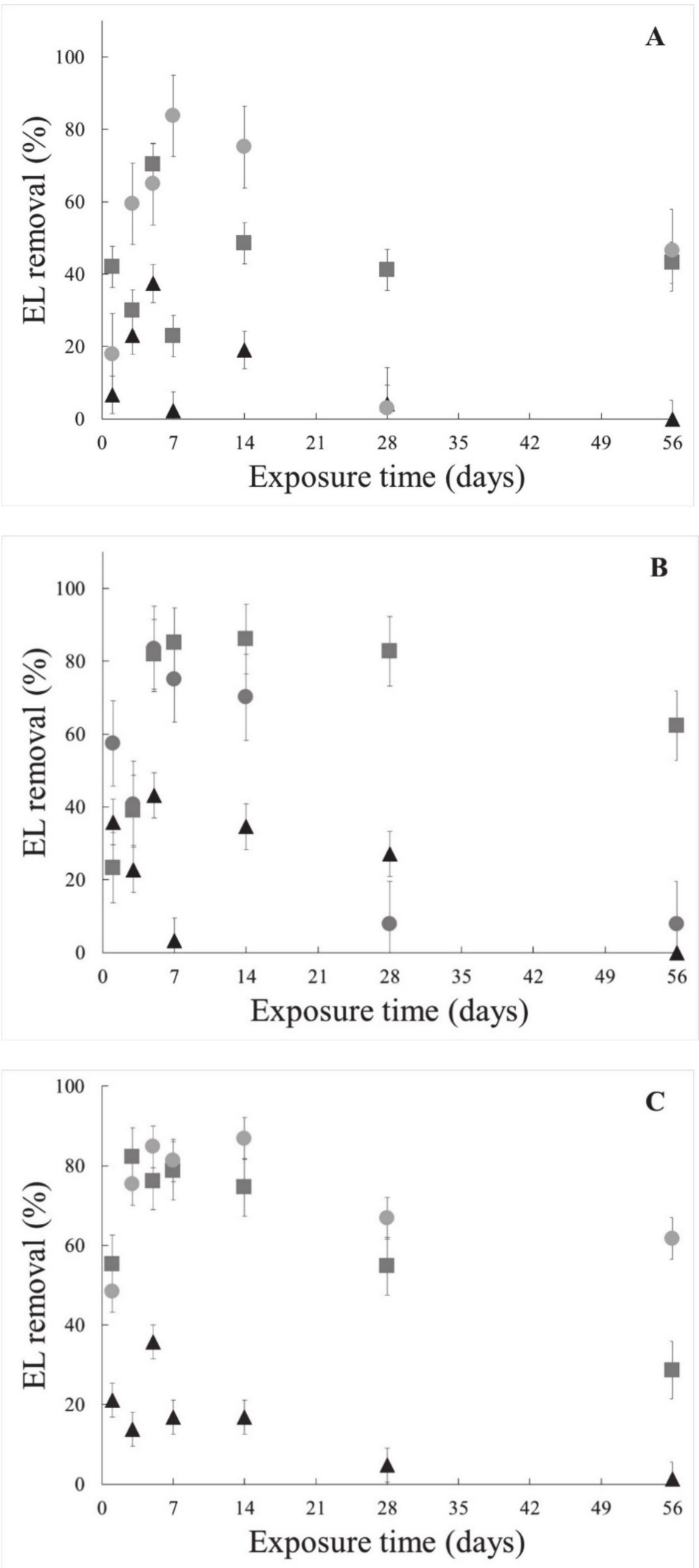

Figure 5. Endosulfan Lactone (EL) removal (\%) on sterile solid substrate with (A) $0.001 \mathrm{mg} / \mathrm{kg}$, (B) $0.004 \mathrm{mg} / \mathrm{kg}$ and $(\mathbf{C}) 0.009 \mathrm{mg} / \mathrm{kg}$ for zero $(\mathbf{\Lambda})$, five $(\boldsymbol{\square})$ and ten $(\bullet)$ earthworms. 
The maximum EL removal occurs between days 5, 7, and 14 with $78 \%$ removal. In experiments without earthworms, removal is observed, having the maximum at day 5 (35\%) and a statistical difference with respect to the remaining days. For days 28 and 56 the removal decreases without statistically significant difference for 5 and 10 earthworms. This suggests that from day 1, earthworms colonized the medium with microorganisms from their gastrointestinal tract which assists the removal process.

\subsubsection{Endosulfan Lactone in Earthworm}

In Figure 6 the presence of EL in earthworm in sterile solid substrate is shown. It can be observed that the highest final concentration is found with 10 earthworms and at the initial concentration of $0.009 \mathrm{mg} / \mathrm{kg}$ without statistically significant difference on day 7 . For initial concentrations of $0.001 \mathrm{mg} / \mathrm{kg}$ and $0.004 \mathrm{mg} / \mathrm{kg}$, the final concentrations found are lower compared to those of the solid substrate non-sterile (Figure 4), this is due to the fact that the earthworm does not ingest the same amount of substrate. That is because the number of microorganisms increase as the experiment continues, thus speeding up vermicomposting process.

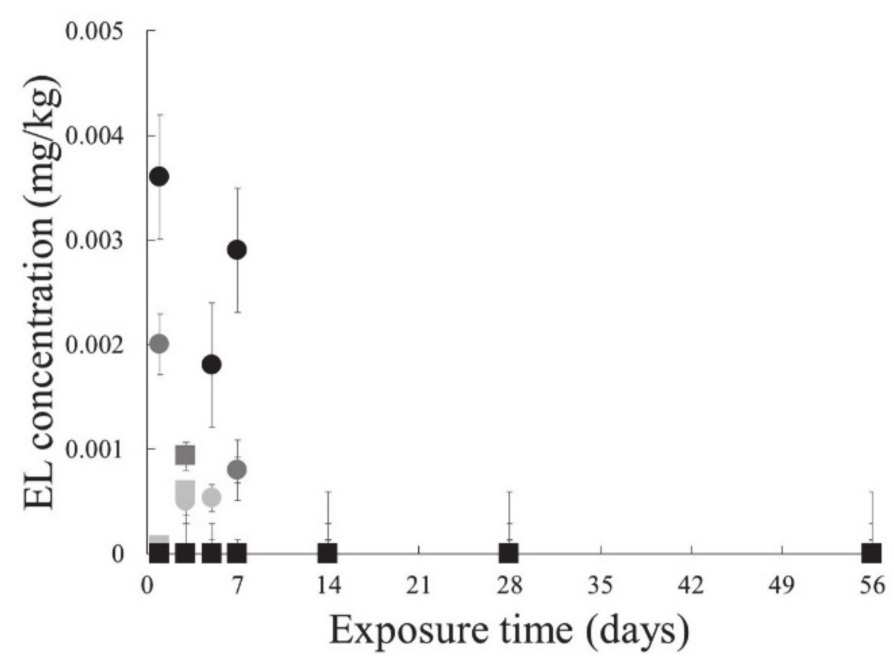

Figure 6. Endosulfan Lactone (EL) concentration for $5(\boldsymbol{\square})$ and $10(\bullet)$ earthworms in sterile solid substrate with $0.001 \mathrm{mg} / \mathrm{kg}(\mathbf{\square}, \bullet), 0.004 \mathrm{mg} / \mathrm{kg}(\boldsymbol{\square}, \bullet)$ and $0.009 \mathrm{mg} / \mathrm{kg}(\mathbf{\square}, \bullet)$.

\subsection{Optimization of Endosulfan Lactone Removal}

The results of the experimental design response surface $3^{2}$, are given as a result of the optimum value for removal (90.86\%), which was just on day 5, with $0.009 \mathrm{mg}$ EL/ $\mathrm{kg}$ and eight earthworms. This can be seen in Figure 7, represented by an asterisk.

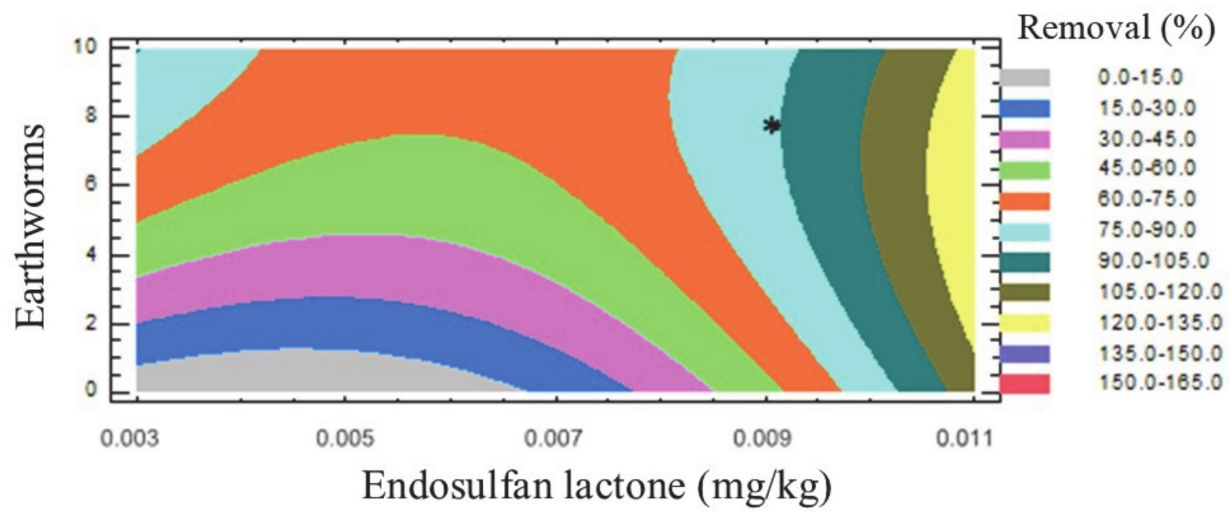

Figure 7. Representation of the response surface using the contour plot for endosulfan lactone removal on day 5 in non-sterile solid substrate. 
The second order polynomial model generated is

$$
O R(\%)=45.5192-215.485[\mathrm{EL}]+16.5857[\mathrm{EW}]+254.861[\mathrm{EL}]^{2}-9.4625[\mathrm{EL}][\mathrm{EW}]-0.5223[\mathrm{EW}]^{2} \mathrm{R}^{2}=97.57 \%
$$

where $O R$ is the optimum removal, [EL] is the endosulfan lactone concentration and $\mathrm{EW}$ is the number of earthworms.

Villalobos-Maldonado et al. [8] evaluated the removal of decachlorobiphenyl using Eisenia fetida and non-sterile conditions, finding a removal of $95.38 \%$ in the first seven days of the experiment, without showing a statistically significant difference between the use of three or five earthworms per experimental unit from an initial decachlorobiphenyl concentration of $200 \mathrm{mg} / \mathrm{L}$. This means that the use of earthworms with microorganisms in the environment where the vermicomposting process is performed, having immersed to the contaminant, play an important role in the process of removal of COPs as polychlorinated biphenyls or pesticides, regardless the use of three or five earthworms.

The optimum removal (\%) generated by the experimental design for sterile solid substrate was $83.86 \%$ on day 14 with 10 earthworms and $0.0045 \mathrm{mg} / \mathrm{kg}$ endosulfan lactone which can be seen in Figure 8 with a diagram of response surface contours.

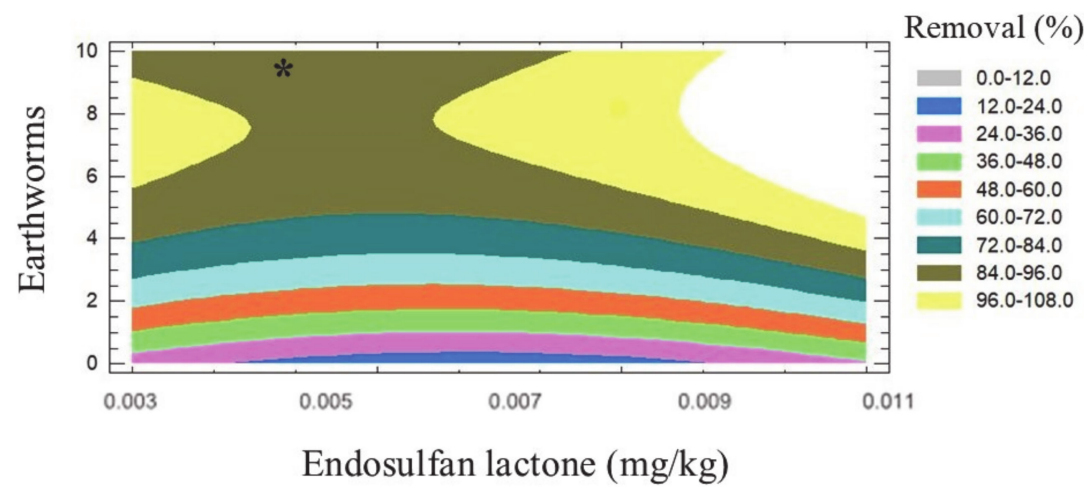

Figure 8. Representation of the response surface by contour plot for endosulfan lactone removal on day 14 in sterile solid substrate.

The second order polynomial equation was

$$
R(\%)=-22.4114-187.693[\mathrm{EL}]+8.874[\mathrm{EW}]-159.657[\mathrm{EL}]^{2}-2.29083[\mathrm{EL}][\mathrm{EW}]-0.492967[\mathrm{EW}]^{2} \mathrm{R}^{2}=91.74 \% .
$$

The presence of microorganisms in non-sterile solid substrate generates higher removal percentages, in less time, compared to the sterile solid substrate.

\subsection{Enzymatic Activity}

For the enzyme activity, the amount of protein present in the extracted microsomes of exposed earthworms to the EL was evaluated; the results are shown in Figure 9.

On day zero no significant statistical difference was found in the amount of Eisenia fetida protein in experiments with or without endosulfan lactone. However, on days 7 and 14 a difference was found between the negative control and experiments containing endosulfan lactone $(0.004 \mathrm{mg} / \mathrm{kg})$, observing the increase at day 7 .

Similar behavior is observed in the polyacrylamide gel (Figure 10): in the negative control (zero days) the bands corresponding to cytochrome P450 are not observed, while at $3,5,7$, and 14 days of substrate exposure with $0.004 \mathrm{mg} / \mathrm{kg}$ is a protein of approximately 50-37 KDa similar to the molecular weight of cytochrome P450, specifically the CYP3A4 subunit $[25,41]$. It is important to clarify that in this protein extract, in addition to CYP450, other enzymatic proteins that can be found in the earthworm, such as superoxide bismutase, glutathione S-transferase, and catalase [42]; lumbrokinase and aldehyde dehydrogenase (among others) are related to earthworm metabolism [43]; in addition to some CYP450 sub units such as CYP1A2, CYP2E1, and CYP3A4 [44]. 


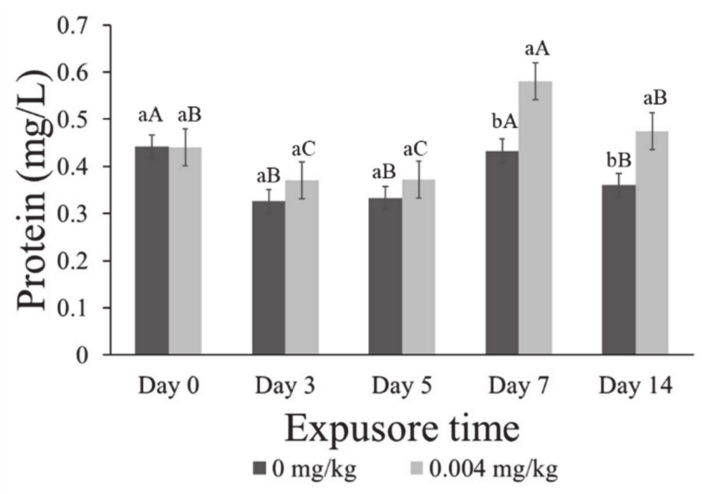

Figure 9. Amount of protein $(\mathrm{mg} / \mathrm{L})$ in Eisenia fetida exposed to endosulfan lactone in solid substrate at $0,3,5,7$, and 14 days. Lowercase letters indicate the statistically significant difference $(p<0.05)$ for each day of exposure and uppercase letters indicate the statistically significant difference $(p<0.05)$ between concentrations.

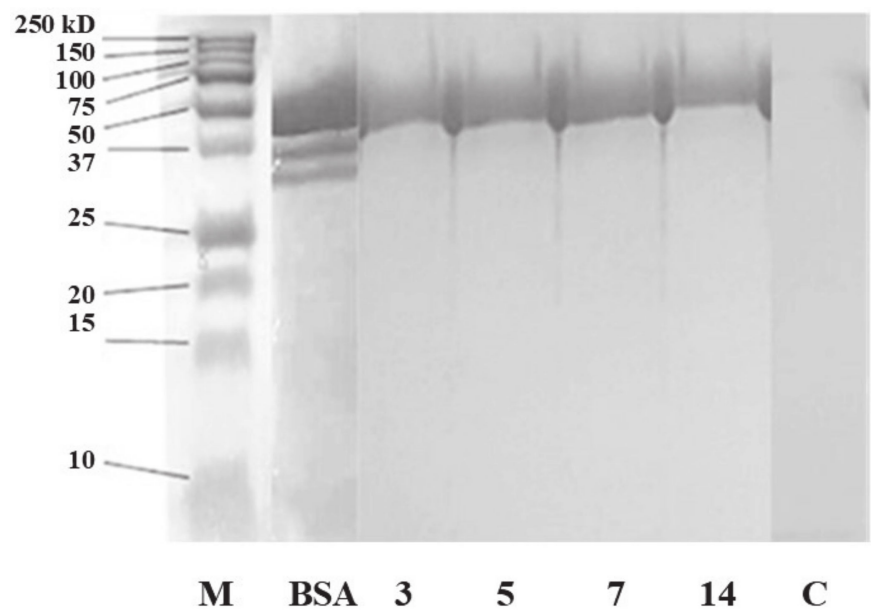

Figure 10. Sodium dodecyl polyacrylamide gel electrophoresis (SDS-PAGE) electrophoretic pattern of microsomes extracted from Eisenia fetida exposed to endosulfan lactone in solid substrate. M (molecular marker), BSA (bovine serum albumin), 3 (earthworms exposed for 3 days), 5 (earthworms exposed for 5 days), 7 (earthworms exposed for 7 days), 14 (earthworms exposed for 14 days), and C (control at 0 days exposition).

Some authors $[45,46]$ have evaluated the presence and activity of the cytochrome P450 subunits in Eisenia fetida exposed to various polluting organic compounds and heavy metals and mention that the expression of this multienzyme complex is higher when the exposure occurs for the first time, However, when the process continues for more than 30 days, a process of adaptation of the earthworm to the exposure of the contaminant is achieved. Similar to the results found in this research, cytochrome is not only expressed when there are dangerous chemical compounds, but also in inorganic molecules that represent a danger to the environment, thus highlighting the diversity of action of the earthworm Eisenia fetida and its ability to help with microorganisms to remove POCs.

The corresponding kinetic parameters are shown in Table 3; in which it is observed that the enzymatic activity increases with respect to the control when Eisenia fetida is subjected to LC50 in solid substrate. The value of $\mathrm{Km}$ with respect to the control increases on the days of sampling, showing greater value of $\mathrm{Km}$ at day 3, but having a lower affinity of the enzyme for the solid substrate. This may be due to the earthworm being immersed in a substrate that serves as support for its survival, but not as food. This solid substrate could contain certain microorganisms that are influencing the participation of other microorganisms-related enzymes; although this was not so in the qualitative test of SDS-PAGE (Figure 10). 
Table 3. Kinetic parameters of the cytochrome P450 enzyme complex in Eisenia fetida exposed for 14 days.

\begin{tabular}{cccc}
\hline $\begin{array}{c}\text { Sample } \\
\text { (Days) }\end{array}$ & $\begin{array}{c}\text { Vmax } \\
(\mu \mathrm{mol} / \mathbf{m i n})\end{array}$ & $\begin{array}{c}\text { Km } \\
(\mu \mathrm{mol})\end{array}$ & $\begin{array}{c}\text { Enzymatic Activity } \\
\text { (mmol/mg Protein } \\
\text { Per min) }\end{array}$ \\
\hline 0 & $0.0155 \mathrm{e}$ & $0.7274 \mathrm{e}$ & $0.2087 \mathrm{e}$ \\
\hline 3 & $0.0187 \mathrm{~d}$ & $3.0458 \mathrm{a}$ & $0.2518 \mathrm{~d}$ \\
\hline 5 & $0.0233 \mathrm{c}$ & $2.7540 \mathrm{~b}$ & $0.3138 \mathrm{c}$ \\
\hline 7 & $0.0346 \mathrm{~b}$ & $2.5489 \mathrm{c}$ & $\mathbf{0 . 4 6 5 9} \mathbf{~ a}$ \\
\hline 14 & $\mathbf{0 . 0 5 0 2 ~ a}$ & $2.0157 \mathrm{~d}$ & $0.3730 \mathrm{~b}$ \\
\hline
\end{tabular}

Letter $(\mathrm{a}, \mathrm{b}, \mathrm{c}, \mathrm{d}, \mathrm{e})$ are significantly different $(p<0.05)$.

Enzymatic activity is greater at day 7 , with a statistical difference compared to the remaining days (Table 3 ) and especially with regard to the control (day zero). Similarly, relative enzymatic activity peaked at day 7 (Figure 11), including a significant statistical difference across the remaining days.

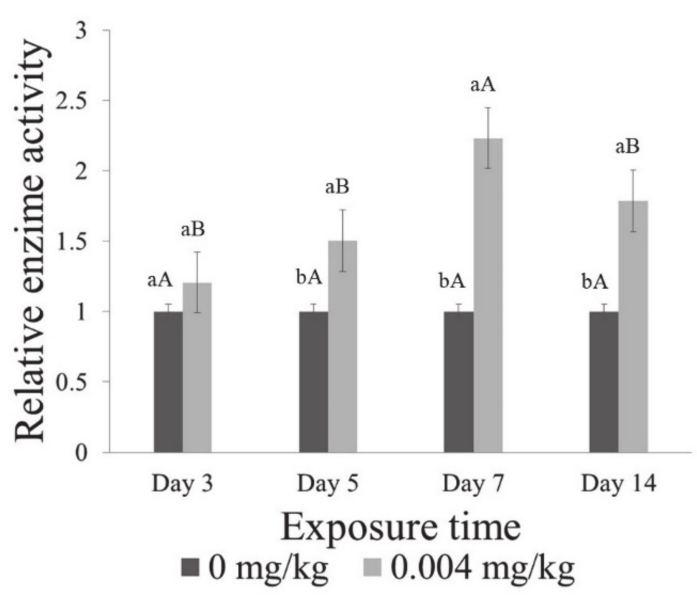

Figure 11. Relative enzyme activity (measured with respect to control), during 14 days of exposure. Lowercase letters indicate the statistically significant difference $(p<0.05)$ for each day of exposure and uppercase letters indicate the statistically significant difference $(p<0.05)$ between concentrations.

These results help explain why earthworms are able to adapt to very different and widely contaminated soils. They also show how earthworms provide important data for ecotoxicology studies, since they function as biomarkers of contaminated soils. Earthworms also signal the presence of enzymes that facilitate biodegradation and biotransformation of contaminants. This is due to the higher protein expression compared with the control and the highest enzyme activity when the earthworm is in a contaminated medium. However, it should be noted that earthworms do not act alone, but also in tandem with microorganisms in the substrate, those in the digestive tract of the earthworm and those that are excreted into the environment. All of which form vermicompost and removing POCs.

\section{Conclusions}

The vermicomposting system using Eisenia fetida was significant for the removal of endosulfan lactone in solid substrate.

The non-sterile solid substrate favored the endosulfan lactone removal process. However, in sterile solid substrate there was removal, demonstrating that earthworms and microorganisms play an important role in these processes, because they improve the conditions in the solid substrate through soil mixing and oxygenation. 
The presence of cytochrome P450 multienzyme complex is an indicator of the presence of contaminants in the solid substrate, due to the increase in enzymatic activity in Eisenia fetida.

By measuring final concentrations in the substrate and in the earthworm, it has found the vermicomposting process can be a sustainable alternative for the removal of EL in the substrate. Further, it was found an optimal removal percentage so that the process could be standardized and applied on agricultural soil with remaining by-products derived from the endosulfan pesticide.

Author Contributions: Conceptualization, R.M.-G.; Data curation, P.T.V.-V. and J.A.-V.; Formal analysis, P.T.V.-V. and J.A.-V.; Funding acquisition, R.M.-G. and J.J.V.-M.; Investigation, P.T.V.-V. and J.A.-V.; Methodology, P.T.V.-V.; Project administration, R.M.-G. and J.J.V.-M.; Resources, R.M.G., F.A.G.-M., J.J.V.-M., and J.A.M.-M.; Software, V.M.R.-V. and F.A.G.-M.; Supervision, R.M.-G.; Validation, V.M.R.-V., F.A.G.-M., J.J.V.-M., J.A.M.-M., and Z.D.; Visualization, V.M.R.-V.; Writingoriginal draft, P.T.V.-V.; Writing-review and editing, P.T.V.-V., R.M.-G., and A.C.-S. All authors have read and agreed to the published version of the manuscript.

Funding: This research received no external funding.

Institutional Review Board Statement: The study was conducted according to the guidelines of the Declaration of Helsinki, and approved by the Ethics Committee of Tecnológico Nacional De México-Instituto Tecnológico De Tuxtla Gutiérrez (August, 2015).

Informed Consent Statement: Not applicable.

Acknowledgments: The authors are grateful to Teresa del Rosario Ayora Talavera and Ana Luisa Ramos Díaz of CIATEJ Mérida, México for the facilities granted to conduct a research stay. The authors are grateful to the National Science and Technology Council and to the National Technology of Mexico/Technological Institute in Tuxtla Gutierrez for financial support (428828).

Conflicts of Interest: The authors declare no conflict of interest.

\section{References}

1. Odukkathil, G.; Vasudevan, N. Residues of endosulfan in surface and subsurface agricultural soil and its bioremediation. J. Environ. Manag. 2016, 165, 72-80. [CrossRef]

2. Bejarano, F.; Souza, J.; Weber, J.M.; Guadarrama, C.; Escamilla, E.; Beristain, B.; Ramirez, F. El Endosulfán y sus Alternativas en América Latina; Red de Acción en Plaguicidas y Alternativas de América Latina: Mexico City, Mexico, 2009.

3. Stockholm Convention on Persistent Organic Pollutants Review Committee. Report of the Persistent Organic Pollutants Review Committee on the Work of Its Fifth Meeting; UNEP/POPS/POPRC.5/10/Add.2; UNEP: Geneva, Switzerland, 2009.

4. Betancurt, L.A.; Ocampo, R.; Ríos, L.A. La problemática del endosulfán: Aspectos químicos, analíticos y ambientales. Luna Azul 2015, 40, 293-313.

5. Stockholm Convention on Persistent Organic Pollutants Review Committee. Report of the Persistent Organic Pollutants Review Committee on the Work of Its First Meeting; UNEP/POPS/POPRC; UNEP: Geneva, Switzerland, 2010.

6. Park, B.-S.; Yoo, J.-H.; Kim, J.-H.; Kim, J.-E.; Lee, S.-E. Biotransformation of endosulfan by the tiger worm, Eisenia fetida. J. Agric. Chem. Environ. 2012, 1, 20-27. [CrossRef]

7. Contreras-Ramos, S.M.; Alvarez-Bernal, D.; Dendooven, L. Characteristics of earthworms (Eisenia fetida) in PAHs contami-nated soil amended with sewage sludge or vermicompost. Appl. Soil Ecol. 2009, 41, 269-276. [CrossRef]

8. Villalobos-Maldonado, J.J.; Meza-Gordillo, R.; Mancilla-Margalli, N.A.; Ayora-Talavera, T.R.; Rodríguez-Mendiola, M.A.; AriasCastro, C.; Vázquez-Villegas, P.T.; Gutiérrez-Miceli, F.A.; Ruíz-Valdiviezo, V.M. Removal of Decachlorobiphenyl in Vermicomposting Process Amended with Rabbit Manure and Peat Moss. Water Air Soil Pollut. 2015, 226, 1-11. [CrossRef]

9. Dendooven, L.; Alvarez-Bernal, D.; Contreras-Ramos, S.M. Earthworms, a means to accelerate removal of hydrocarbons (PAHs) from soil? A mini-review. Pedobiologia 2011, 54, S187-S192. [CrossRef]

10. Villalobos-Moldonado, J.J.; Meza-Gordillo, R.; Enciso-Sáenz, S.; Castañon-González, J.H.; Rosales-Quintero, A.; Lagu-nas-Rivera, S.; Rincón-Rosales, R. Identificación molecular de bacterias en Eisenia fetida Savigny cultivadas, con potencial de remoción de contaminantes orgánicos persistentes. Agroproductividad 2017, 10, 51-56.

11. NOM-021-RECNAT-2000. Establece las especificaciones de fertilidad, salinidad y clasificación de suelos. Estudios, muestreos y análisis. Diario Of. Fed. 2000, 14, 17.

12. Walkley, A.; Black, I.A. An examination of the degtjareff method for determining soil organic matter, and a proposed modification of the chromic acid titration method. Soil Sci. 1934, 37, 29-38. [CrossRef]

13. Durán, L.; Henríquez, C. Caracterización química, física y microbiológica de vermicompostes producidos a partir de cinco sustratos orgánicos. Agron. Costarric. 2007, 31, 41-51. 
14. Organization for Economic Cooperation and Development OECD. Earthworm, acute toxicity test-207. In OECD Guideline for Testing of Chemicals; OECD Publishing: Paris, France, 1984. [CrossRef]

15. Vazquez-Villegas, P.T.; Meza-Gordillo, R.; Gutiérrez-Miceli, F.A.; Ruiz-Valdiviezo, V.M.; Villalobos-Maldonado, J.J.; MontesMolina, J.A.; Fernadez-Toledo, A.A.J. Determinación de CL50 y CE50 de endosulfán lactona y diazinón en lombriz de tierra (Eisenia foetida). Agroproductividad 2018, 11, 105-111.

16. Peñaloza, G.S.A.; Rincon, D.J.P.; Restrepo, L.G.C. Evaluation of wet sterilization and microwave sterilization of two types of soil. Rev. Científica 2013, 1, 87-93.

17. Li, W.; Dai, Y.; Xue, B.; Li, Y.; Peng, X.; Zhang, J.; Yan, Y. Biodegradation and detoxification of endosulfan in aqueous me-dium and soil by Achromobacter xylosoxidans strain CS5. J. Hazard. Mater. 2009, 167, 209-216. [CrossRef] [PubMed]

18. Vázquez-Villegas, P.T. Toxicological and Physiological Responses of Eisenia fetida Exposed to Endosulfan Lactone. Ph.D. Thesis, Tecnológico Nacional de México/IT Tuxtla Gutiérrez, Chiapas, Mexico, 2019.

19. Vázquez-Villegas, P.T.; Meza-Gordillo, R.; Luján-Hidalgo, M.C.; Cruz-Salomón, A.; Ruíz-Valdiviezo, V.M.; Gutiérrez-Miceli, F.A.; Montes-Molina, J.A. Optimization and validation of an extraction method for endosulfan lactone on a solid substrate. Processes 2021, 9, 284. [CrossRef]

20. Mosleh, Y.Y.; Couderchet, M.; Vernet, G. Acute and sublethal effects of two insecticides on earthworms (Lumbricus terrestris L.) under laboratory conditions. Environ. Toxicol. 2003, 18, 1-8. [CrossRef]

21. Aguilar-Vázquez, J. Bioacumulación y Eliminación de Endosulfán Lactona en Eisenia fetida. Master's Thesis, Tecnológico Nacio-nal de México/IT Tuxtla Gutiérrez, Chiapas, Mexico, 2019.

22. Islam, M.A.; Sakkas, V.; Albanis, T.A. Application of statistical design of experiment with desirability function for the removal of organophosphorus pesticide from aqueous solution by low-cost material. J. Hazard. Mater. 2009, 170, 230-238. [CrossRef]

23. Layne, E. Spectrophotometric and turbidimetric methods for measuring proteins. In Methods in Enzymology; Academic Press: Cambridge, MA, USA, 1957; Volume 3, pp. 447-454.

24. Zhang, T.; Zhu, Y.; Gunaratna, C. Rapid and quantitative determination of metabolites from multiple cytochrome P450 probe substrates by gradient liquid chromatography-electrospray ionization-ion trap mass spectrometry. J. Chromatogr. B 2002, 780, 371-379. [CrossRef]

25. Cao, X.; Song, Y.; Kai, J.; Yang, X.; Ji, P. Evaluation of EROD and CYP3A4 activities in earthworm Eisenia fetida as biomarkers for soil heavy metal contamination. J. Hazard. Mater. 2012, 243, 146-151. [CrossRef] [PubMed]

26. Laemmli, U.K. Cleavage of structural proteins during the assembly of the head of bacteriophage T4. Nature 1970, 227, 680-685. [CrossRef]

27. Li, W.; Xiao, N.W.; Liu, X.H.; Ge, F. Effect of herbicide acetochlor on cytochrome P450 monooxygenases and GST of earthworms Eisenia fetida. J. Environ. Sci. China 2006, 18, 135-140.

28. Perdomo, C.; Barbazán, M.; Durán, J. Área de Suelos y Aguas. CÁTEDRA de Fertilidad; Universidad de la Republica: Motevideo, Uruguay, 2003.

29. Castillo-Cerma, C.M. Selección y Calibración de Indicadores Locales y Técnicos para Evaluar la Degradación de los Suelos Lade-ras, enla Microcuenca Cuscamá el Tuma. Bachelor's Thesis, Universidad Nacional Agraria, Managua, Nicaragua, 2005.

30. Vanegas, A.F.C. Relación del Carbono y Nitrógeno del Suelo con Usos y Coberturas del Terreno en Alcalá, Valle del Cauca. Ph.D. Thesis, Universidad Tecnológica de Pereira, Pereira, Risaralda, 2008.

31. EPA. Ecological Effects Test Guidelines; OPPTS 850.4225 Seedling Emergence, Tier II; National Service Center for Environmental Publications: Washington, DC, USA, 1996.

32. Vijver, M.; Wolterbeek, H.; Vink, J.P.; Vangestel, C. Surface adsorption of metals onto the earthworm Lumbricus rubellus and the isopod Porcellio scaber is negligible compared to absorption in the body. Sci. Total Environ. 2005, 340, 271-280. [CrossRef]

33. Coutiño-González, E.; Hernández-Carlos, B.; Gutiérrez-Ortiz, R.; Dendooven, L. The earthworm Eisenia fetida accelerates the removal of anthracene and 9, 10-anthraquinone, the most abundant degradation product, in soil. Int. Biodeterior. Biodegrad. 2010, 64, 525-529. [CrossRef]

34. Ali, M.; Kazmi, A.; Ahmed, N. Study on effects of temperature, moisture and $\mathrm{pH}$ in degradation and degradation kinetics of aldrin, endosulfan, lindane pesticides during full-scale continuous rotary drum composting. Chemosphere 2014, 102, 68-75. [CrossRef]

35. Verma, K.; Agrawal, N.; Farooq, M.; Misra, R.; Hans, R. Endosulfan degradation by a Rhodococcus strain isolated from earthworm gut. Ecotoxicol. Environ. Saf. 2006, 64, 377-381. [CrossRef]

36. Kong, L.; Zhang, Y.; Zhu, L.; Wang, J.; Wang, J.; Du, Z.; Zhang, C. Influence of isolated bacterial strains on the in situ biodegradation of endosulfan and the reduction of endosulfán-contaminated soil toxicity. Ecotoxicol. Environ. Saf. 2018, 160, 75-83. [CrossRef] [PubMed]

37. Viñas Canals, M. Biorremediación de Suelos Contaminados por Hidrocarburos: Caracterización Microbiológica, Química y Ecotoxicológica. Ph.D. Thesis, Universidad de Barcelona, Barcelona, Spain, 2005.

38. Adhikary, S. Vermicompost, the story of organic gold: A review. Agric. Sci. 2012, 3, 905-917. [CrossRef]

39. Kauschke, E.; Mohrig, W.; Cooper, E.L. Coelomic fluid proteins as basic components of innate immunity in earthworms. Eur. J. Soil Biol. 2007, 43, S110-S115. [CrossRef]

40. Bilej, M.; Procházková, P.; Šilerová, M.; Josková, R. Earthworm Immunity. Adv. Exp. Med. Biol. 2010, 708, 66-79. [CrossRef] 
41. Qiu, X.; Li, W.; Tian, Y.; Leng, X. Cytochrome P450 monooxygenases in the cotton bollworm (Lepidoptera: Noctuidae): Tissue difference and induction. J. Econ. Entomol. 2003, 96, 1283-1289. [CrossRef] [PubMed]

42. Ji, C.; Wu, H.; Wei, L.; Zhao, J.; Lu, H.; Yu, J. Proteomic and metabolomic analysis of earthworm Eisenia fetida exposed to different concentrations of 2,2',4,4'-tetrabromodiphenyl ether. J. Proteom. 2013, 91, 405-416. [CrossRef]

43. Wang, X.; Chang, L.; Sun, Z.; Zhang, Y. Comparative proteomic analysis of differentially expressed proteins in the earth-worm Eisenia fetida during Escherichia coli O157: H7 stress. J. Proteome Res. 2010, 9, 6547-6560. [CrossRef] [PubMed]

44. Lu, X.; Li, Y.; Thunders, M.; Cavanagh, J.; Matthew, C.; Wang, X.; Zhou, X.; Qiu, J. Differential protein expression and localization of CYP450 enzymes in three species of earthworm; is this a reflection of environmental adaptation? Chemosphere 2017, 171, 485-490. [CrossRef]

45. Achazi, R.K.; Flenner, C.; Livingstone, D.R.; Peters, L.D.; Schaub, K.; Scheiwe, E. Cytochrome P450 and dependent activities in unexposed and PAH-exposed terrestrial annelids. Comp. Biochem. Physiol. Part C Pharmacol. Toxicol. Endocrinol. 1998, 121, 339-350. [CrossRef]

46. Cao, X.; Bi, R.; Song, Y. Toxic responses of cytochrome P450 sub-enzyme activities to heavy metals exposure in soil and correlation with their bioaccumulation in Eisenia fetida. Ecotoxicol. Environ. Saf. 2017, 144, 158-165. [CrossRef] [PubMed] 